\title{
Narratives that Inform Pre-service Secondary English Teachers' Writing Instruction and Pedagogy
}

\author{
Elsie L. Olan \\ University of Central Florida \\ Orlando, Florida-USA
}

\begin{abstract}
This qualitative inductive study of pre-service secondary English teachers (PSETs) focuses on ways PSETs think about teaching writing, the kinds of stories they draw on when learning to teach writing and what role, if any, do these stories play in their storied responses during a methods course experience. This study encompasses a convenience sample of four pre- service secondary English teachers' (PSETs) learning, teaching, and writing instruction experiences in their Language and Literacy methods course (LLED XXX). Most preservice secondary teachers (PSETs) have their definition of writing instruction and set out expectations as English teachers before they enter their teaching training programs. Yet at some point during their methods course experience, these expectations seem to change. Findings indicate that PSETs draw on contrasted stories of past and present experiences in one of three thematic categories: stories about a beloved teacher, about writing, and about authenticity. They identify, invoke and note contrasts between their own learning experiences as students, the beliefs they had come to hold about writing instruction and their set out expectations as English teachers via methods courses and preteaching experiences. PSETs storied responses about their writing process and writing instruction depicted a causal relationship characterized as one of mediation and self-discovery.
\end{abstract}

\section{Introduction}

Most pre-service secondary English teachers (PSETs) have their definition of writing instruction before they enter their teaching training programs. They feel they have a clear understanding of their responsibilities and have set out expectations as English teachers. Yet at some point during their methods course experience, these expectations seem to change.

According to Petraglia [39] "changes in human behavior and consciousness, individual or collective, are mediated by other human beings through the use of tools". These tools can be symbols or artifacts loaded with meaning. PSETs have had exposure to many texts and "historically situated" experiences and interactions, thus encountering internal transformations that in turn influence their understandings of writing instruction and teaching expectations. Vygotsky's [46] “zone of proximal development," is where ions that in turn influence their understandings of writing instruction and teaching expectations.

Social constructivist views such as Lev Vygotsky's stress that group learning and peer collaboration is useful [46]. Tools derived historically and culturally for the development of higher thinking skills mediate effective writing instruction and writing. Vygotsky's Mind in Society [47] identifies the distinction prevalent between tools as a means of labor of mastering nature, and language as a means of social intercourse and how they become dissolved in the general concept of artifacts learners engage in tasks with the aid of peers or any tools that improve language learning. Poehner [40] referenced how Vygotsky and his colleagues accepted Marx's crucial insight that "human beings shape and are shaped by their environments through concrete activity mediated by physical tools" [34]. The tools transform the world where the use of tools is an active and creative process. The physical and psychological tools enable PSETs to predict the results of certain actions. PSETs would be acting in intentional and purposeful manners. Finally, these physical tools acquire meaning as they converge with psychological tools. The relations and ideas in psychological tools become internalized and these tools are transformed for thinking, learning and writing. These tools (writing experiences and PSETs' stories) offer PSETs a set of affordances that impact how they will act in their teaching and learning environment, thus transforming their environment and themselves.

For PSETs, incorporating writing experiences in their methods courses that are related to their interests and concerns and made pertinent to their field of study may lead to the acquisition of knowledge and the enhancement of writing instruction. Effective instruction promotes active and meaningful learning.

\section{Narrative pedagogy}

As Connelly and Clandinin suggest, the retelling and rewriting of teachers' stories might conceivably lead to awakenings, transformations, and quite possibly changes in teachers' school and classroom practices [14]. By writing their own personal and professional lives in narrative form, teachers may reveal their own sense of agency that illustrates the extent to which they, as educators, can use, modify 
and claim their lived experiences as their own meanings that matter most to them. In fact, what narrative inquiry manifests is that the combined circulation of experiences and ideas mediated through personal agency with a learning community in essence results in a collective portrait of the complexities of school and classroom practices [7], [14], [60], [63].

The use of descriptive narratives of school experiences can initiate the kinds of conversations and research that is imperative for teacher development and implicit in the everyday trials and tribulations present in educational institutions. Moreover, the constant interplay of multiple and often, conflicting professional and personal narratives generate significant educational reflective and critical research [7].

The study of narrative pedagogy - as indicative in the research on reflective practice, life history and autoethnography - has its origins in the collection of interpretive 'thick descriptions' as developed by anthropologists and others [26], [30]. They have also developed a sociocultural approach to pedagogy.

Barkhuzien, Benson, and Chik noted that the use of written narrative for understanding pedagogy has emerged as a common methodolgy in the field of teacher studies [2]. In particular, educational theorist and practitioners have noted the use of qualitative data in shaping teacher knowledge has become more and more prevalent in academic studies [3], [31],[48],[59],[44]. Golombeck \& Johnson underscored how qualitative research is most positioned to reveal how 'teachers come to know, as well as what they come to know, [32], p. 312).

Narrative pedagogy aims to explore how individuals, and in this case, teachers develop their intercultural knowledge and its influence in shaping their future role and practice as teachers; it is concerned with teachers' holistic attitude towards knowledge and its relationship to practice [12].

Narrative inquiry recognizes that teacher storytelling is a valid research tool. It acknowledges that research can be conducted from different perspectives - administrator, teacher, and learner and that each inquiry and response is valid in and of itself. The acknowledgment of different viewpoints reminds researchers that any narrative is a 'partial telling,' and that recognition of these perceptions are essential to understanding narrative inquiry.

The current approaches to teacher education reflect a 'social view of knowledge creation that stresses its highly situated, relational, active and experiential nature'; knowledge is recognized as a 'contextualized part of specific relationships, cultures and situations [36]. This social constructionist view of teacher knowledge expects that teachers and/or practitioners will bring their previous knowledge and experience to new learning situations, and 'to ground experience in theory [7].
Thus, prospective teachers engage in not a onetime process of training and intermittent staff development, but active life-long professional studies which requires opportunities for teachers to link prior knowledge to new understandings through reflective practice. The cultivation and edification of reflective teachers and teaching, 'has to be imbued with ideas of self-evaluation, inquiry into practice and critical exploration of practice and experience set against theoretically sound principles, in order to make judgement about teaching and learning," [25].

Teacher development is a life-long process. When seeking to develop professional competencies, the benefits associated with practice-oriented knowledge are predicated on the notion that teacher self-improvement and empowerment develop through narration, reflection and self-expression [10]. Life stories represent the outward articulation of a teacher's inner scrutiny. Using autobiography as pedagogy, contends that a particular teacher's narrative demonstrates that belief or life value is worthwhile for professional learning.

\section{How stories reflect development of teachers}

Life history approaches are widely used in the study of teachers' lives and of teachers' thinking and personal and professional development (Carter [5],[6],[11],[13], ,[14 [20]; [ 33]; [48]. Life history approaches include using teachers' narratives, autobiographies, and other forms of writing in teacher education [1], [12], [15], [18], [19], [24], [34], [40], [42], [35].

Life history and narrative research are not necessarily seen as different approaches but the description of the quality of the studied experience is interpreted differently in each [14]. Narrative, as an approach, centers on understanding personal experience. This understanding of personal experience extends to the way teachers make meaning of the experience lived and shared. According to Miller [49], the idea of using narrative in teacher education was pioneered by Jean Clandinin and Michael Connelly. For them, narrative is not only the texts we read, but also a way to think about teaching and learning as well as research into teaching and learning [7].

Narratives are examined in order to learn how to appreciate the wider context of PSETs' lives to understand their narrative accounts, and how these personal stories can illustrate their teacher development and teacher identity formation. Reissman [41] suggests, that the reported narrative form arguably gives stories more power than even the resistant subversive acts. Telling the story "makes the moment live beyond the moment".

According to Miller [49], many teacher educators use narrative to better understand how our personal 
experiences impact what we believe about teaching and how we engage in practice. In this study, even though the researcher did not set out to collect preservice secondary English teachers' (PSETs) narratives, the emerging stories were salient as data was reviewed. The researcher revisited data and identified the crucial role stories occupied in regards to PSETs' responses. It was through these narratives that PSETs shared their learning, experiences, identity and conflicts while shaping their understandings of their teacher development.

\section{Purpose of study}

This qualitative inductive study of pre-service secondary English teachers (PSETs) in the methods course focused on how they think about the teaching of writing, kinds of stories they draw on when learning to teach writing and what role, if any, do these stories play in their storied responses during a methods course experience.

In this study, stories were selected as the unit of analysis because these narratives produce, elicit, or express the phenomenon under investigation. One primary observation was the triadic nature of these stories. PSETs' stories were about their student experiences, past and present teacher experiences, and experiences as pre-service secondary English teachers (PSETs). These stories were enhanced by a dichotomous nature of the PSETs' roles as young adult students (that still engage in writing activities) and pre- service educators (teaching writing). PSETS were also aware of these two identities, and recognized a potential relationship between their 'actual' behavior and perceptions about the intentions or beliefs surrounding their actions.

The functional system where PSETs engaged in common tasks was the classroom setting.

This setting consisted of PSETs, teacher educator, common tasks, and words that make meaning while "mediating the interaction" Engström [17]. This mediation involved history and culture that was embedded within each activity, story, and was distinctive of each PSET.

\section{Research questions}

What stories do pre-service secondary English teachers (PSETs) draw on when learning to teach writing?

What role, if any, do these stories play in their storied responses during a methods course experience?

\section{Views on teaching writing}

Writing is a challenging task, and teaching how to write is a process. Emig [16] emphasized how writing compared to speech is a much slower process that develops gradually by changes. These changes are encouraged by connecting events or experiences of the past, present, and future to the different meanings they may have in the writers' lives. "Writing is epigenetic, with the complex evolutionary development of thought steadily and graphically visible and available throughout as a record of the journey" [16]. PSETs engage in the teaching of writing by developing their ability to make meaning of experiences and connect these to their social environment.

Lortie [35] further found that teachers have a difficult time overcoming past images from their own schooling and teaching, and therefore might have a limited view of learning. Thus pre-service students might replicate teaching methods they experienced as students without understanding their teachers' goals in using them. Grossman \& Richert [28] found that pre- service teachers often rely on their memories of themselves as students to anticipate what their own students will be like, using "their memories of their interests and abilities in a particular subject matter to inform their knowledge of student understanding in that area".

For Kennedy [32], Darling-Hammond [11], and North [38] teacher educators and teaching practices are affected by experiences, assumptions, attitudes, prior beliefs, and duration of teacher education programs. Kennedy's studies [32] established a link between teachers' beliefs about teaching writing and their own experience with writing. Her research concluded that "the brevity of teacher programs, participants' prior beliefs regarding teaching and writing, and a minimum amount of programs with coherent vision of teaching do not change participants' beliefs about learning, writing, and teaching" [32]. Kennedy [32] established the need for teacher education programs that provide opportunities where pre-service English teachers "rethink the assumptions they bring with them from their childhood".

Darling-Hammond [11] reiterated these ideas throughout her research. Her studies posited how "teacher educators need to find ways to help teachers temper their initial ideas about the teaching of writing with new ideas about the teaching of writing". Her studies further develop and help contextualize North's [38] description of how teaching practices are passed down. North explained how teaching practices are often passed from one generation to another through conversations or the interaction and exchange of knowledge and pedagogical practices amongst teachers. These studies and research frame the researcher's concerns with pre-service secondary English teachers learning to teach writing.

In Answering Your Questions about Teaching Writing: A Talk with Donald Graves [26], Graves 
states: "Twenty-four of our states don't even offer a course of writing for a teacher-intraining to take". Graves stated this in 1996, and nineteen years later there are more courses attending teaching writing, but there are still gaps. Precisely, this is one of the greatest problems for PSETs because in- service workshops would not sufficiently meet their need of getting well prepared to teach writing. "Writing represents a unique mode of learning- not merely valuable, not merely special, but unique" [16]. It is through learning how to teach writing that PSETs gauge writing as an active process of generating ideas, exploring and reinforcement. Emig [16] had previously reported in The Composing Processes of Twelfth Graders how "school- sponsored writing experienced by older American secondary students is a limited, and a limiting experience". PSETs would be exposing students to writing experiences that move them from passive learners to learners that generate ideas, observations, and emotions. The product of this process is visible and permits review, intervention, and modification of knowledge as it is learned and put into a framework (Emig [16]; Fulwiler [20]; Tomlinson [45]. Flower and Hayes [18] further followed Emig's work by using "think aloud" to establish the difference between proficient and less-proficient writers. Students were able to articulate their thought as they wrote, thus enabling the researchers to determine that proficient writers were overly aware of their audience versus lessproficient writers who did not invest too much time thinking about their audience. When looking at writing in their studies, Flower and Hayes [18] posited the following: there is a difference between the composing processes between writers, writing can be perceived as a problem-solving activity, goals must be set and direct composing, and the composing process is interconnected.

All of these eventually became tenets of the writing process movement. Through writing instruction courses the teaching of writing is reinforced. PSETs practice writing and teaching writing as a mode of learning.

The teaching of writing requires knowledge of how the demands of writing vary depending upon the nature of the task, audience, and genre, among other factors. Lack of this knowledge among teachers may help explain why writing instruction too often reduces the writing process to a lock-step series of discrete stages [27].

\section{Method}

According to Strauss and Corbin [44], the inductive design is evident in several types of qualitative data analyses, especially grounded theory. The data was analyzed inductively because the researcher did not search out data or evidence to prove or disprove hypotheses before beginning this study.

When looking and coding data, the researcher used a grounded theory analytical approach. The researcher allowed concepts to emerge rather than approaching with a lens already in hand. In 1967, Glaser and Strauss [22] first introduced grounded theory. Glaser defined grounded theory as a theory based "on the systematic generating of theory from data that in itself is systematically obtained from social research". Strauss and Corbin's [43] definition of grounded theory further explicated how data collection continuously evolves new questions for the analysis. This definition is clear and concise.

For this study's purpose, Glaser and Strauss' [22] grounded theory was enhanced with Charmaz's [6] definition for grounded theory method. For Charmaz [6], "grounded theory methods consist of systematic, yet flexible guidelines for collecting and analyzing qualitative data to construct theories 'grounded' in the data themselves". The goal of a grounded theory study is to "demonstrate relations between conceptual categories and to specify the conditions under which theoretical relationships emerge, change, or are maintained" Charmaz [5]. The goal of using grounded theory in this research was not to establish relationships but to uncover some of those relationships that can exist between stories PSETs draw on.

Using a grounded theory analytical approach to code data, enabled the researcher to initially code data line- by-line, compare categories and stories (story lines), revisit data and compare it to emergent data, question the theoretical categories data indicated, and constantly compare categories with one another in order to uncover relationships and possible groupings. In this study researchers did not seek to identify an emerging theory, nor was it evident through the continuous interplay between analysis and data collection, therefore this study is not a grounded theory research.

Using grounded theory to code data contributed to the qualitative inductive design of this study because frequently reported clear patterns, codes and categories were revealed and used in the data analysis. This aided the researcher's understanding of PSETs' contrasting past and present experiences and stories.

Data was collected and coded while providing further understanding to the main concerns involved in the following questions: (1) What stories do PSETs draw on when learning to teach writing? (2) What role, if any, do these stories play in their storied responses during a methods course experience?

These research questions were examined based on PSETs' storied responses to artifacts, specifically the interview, reflections, and stories. 
A connection and contrast between stories of past and present experiences was established. Experience and or experiences were defined according to PSETs' contextual realities (see Table 2). This was followed by a discussion of the results of themes related to stories (see Table 1). The researcher then moved to different forms of storytelling prevalent in PSETs' stories in the methods course perceived as invitations elicit reflection and differences between approaches previously learned and writing as a process. PSETs' responses were incorporated to the interview to further explore PSETs' reaction toward their stories (see Table 1).

The focus of the analyses was on stories PSETs told. Telling or sharing teacher stories was one way for pre- service secondary English teachers (PSETs) to gain insight of ideas, issues, and concerns prevalent in their narratives (see Table 1).

Table 1. Frequency of stories

\begin{tabular}{|c|c|}
\hline & Interview \\
\hline Leah & 7 \\
\hline Riley & 26 \\
\hline Jessie & 20 \\
\hline Mathew & 16 \\
\hline Total of stories & 69 \\
\hline
\end{tabular}

PSETs revisited an event or a series of events while exploring issues and concerns particular to teaching experiences. As PSETs shared their stories, they analyzed and interpreted their pedagogical beliefs, practices and expectations. It was through this telling of their stories that PSETs made sense and preserved experiences while sharing their own writing process and writing instruction.

\section{Conclusions}

The research questions were examined based on PSETs' storied responses to the interview (see Appendix A). A connection and contrast between stories of past and present experiences was established. Experience and or experiences were defined according to PSETs' contextual realities. This was followed by a discussion of the results of themes related to stories.

Telling or sharing teacher stories was one way for pre-service secondary English teachers (PSETs) to gain insight of ideas, issues, and concerns prevalent in their narratives (see Table 1).

A primary way individuals make sense of experience is by casting it in narrative form (Bruner [4], Gee [21]; Mishler [37]. In the stream of consciousness involved in the telling of stories, PSETs reflected, remembered, revisited and (re) discovered the feelings associated with the experience lived or recollected (See Table 2). The expression of feelings through this narrativization not only 'talked' about past events or actions, but how PSETs (storytellers) understood the actions and how they chose to express feelings aroused by the meaning attributed to the action or experience (see Table 2).

Table 2: Final themes for analysis in research Questions 1 and 2

\begin{tabular}{|c|c|c|c|c|c|}
\hline & 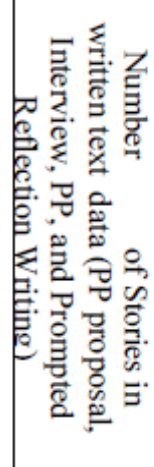 & 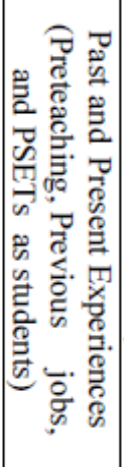 & 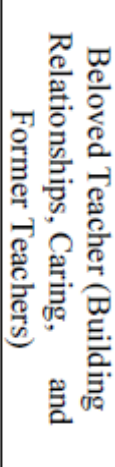 & 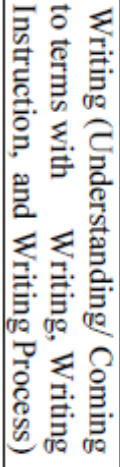 & 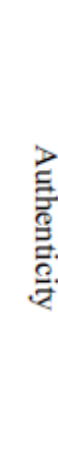 \\
\hline Leah & 14 & 12 & 7 & 4 & 4 \\
\hline Riley & 30 & 20 & 13 & 20 & 6 \\
\hline Jessie & 33 & 26 & 19 & 34 & 9 \\
\hline Mathew & 30 & 27 & 9 & 34 & 8 \\
\hline Total & 107 & 85 & 48 & 92 & 27 \\
\hline
\end{tabular}

Through teacher stories PSETs encountered a process of self-discovery and growth in multiple ways. Jalongo [41] identified five significant ways in which teacher stories contribute to self-discovery and growth. "Teachers' stories invite reflective practice, chronicle growth and change, promote the "ethic of caring", help teachers to find their voice, and enhance cross-cultural understandings". Talking and sharing their stories helped PSETs understand themselves, revisit their previous experiences with teachers and teaching, and raise questions about teachers, teaching and their expectations. PSETs' stories are topic-centered a narratives. KohlerReissman [45], defines topic- centered narratives as stories that are snapshots of past events and are linked thematically. Data presented stories of past and present events; these were thematically coded, categorized and reexamined using experience as an overarching theme.

This study's research questions asked: (1) What stories do pre-service secondary English teachers (PSETs) draw on when learning to teach writing? (2) From What role, if any, do these stories play in their storied responses during a methods course experience? From analysis related to this question, several findings emerged.

\subsection{Finding 1}


PSETs draw on contrasted stories of past and present experiences in one of three thematic categories: stories about a beloved teacher, stories about writing, and stories about authenticity (see Table 2). As indicated by data, PSETs in this study most often identified and described experiences through three key words that appeared again and again across the data set. Each of these words portrayed a theme.

After a seventh, eighth, and ninth pass of the data set, the three key words (themes) remained as descriptors of PSETs' experiences throughout their stories. PSETs told stories about beloved teachers, writing, and authenticity. As they told stories of contrasted past and present experiences, these stories took one of three forms. Some of the different forms of telling stories employed by PSETs were sharing informed incidents, disclosing uncertainties, and/ or beliefs.

\subsection{Finding 2}

PSETs invoked different forms of telling their stories where they identified and noted contrasts between their own learning experiences as students and the beliefs they had held about writing instruction and their set out expectations as English teachers via methods courses and pre-teaching experiences. These stories confirmed what Flyvbjerg [24] described in his work about case studies and narrative; namely, that "good narratives typically approach the complexities and contradictions of real life" (p. 306). While working with their interview, PSETs identified contrasted storied past and present experiences and were able to reflect on the complexities and contrasted view that each story brought into the formation of their teaching identity, pedagogical practices, and beliefs.

\subsection{Finding 3}

PSETs' storied responses about their writing process and writing instruction depicted a causal relationship between their writing processes and how they teach writing (writing instruction). PSETs describe this process as a recursive one where these causal relationships are revisited and depicted as one of understanding and /or coming to terms with how their writing process plays an integral part of their writing instruction. PSETs characterized this process as one of mediation. Their storied responses about their writing process and instruction had a mediating role.

\section{Implications}

When PSETs revisited contrasted past and present experiences, teacher educators were provided with insights as to the teacher-student interaction. If teacher educators provided or fostered invitations or activities throughout the methods courses where PSETs were exposed to reflective and reflexive practices and narrative writings, PSETs could acknowledge, analyze and interpret their experiences.

These invitations (interview/ reflections) should foster opportunities where PSETs can enhance their ability to reflect on their lessons, articulate their pedagogical beliefs, values and practices while participating of academic discussions, and critically reflect on the practice of teaching.

Teacher educators still have much to learn about PSETs selecting and implementing these reflective and reflexive practices to teaching practices they are learning in the methods course. These stories are a powerful way of meaning making for students who aspire to becoming teachers. Teacher educators may use PSETs' stories to mediate students' writing process and writing instruction while revisiting their pedagogical practices and beliefs.

Teacher educators can provide outlets for PSETs to articulate contrasted past/ present experiences with writing or writing instruction, and becoming a teacher.

Teacher educators ought to use these narratives to help PSETs "unpack" their "baggage of experiences" (lived or appropriated experiences) while telling their stories. The interview (see Appendix A), narratives and reflections, as tools, were prevalent throughout the methods course, and the stories they elicited became "teaching moments" where conversations occurred about pedagogical beliefs, practices and writing instruction. Methods instructors need to be mindful of the mediating role stories take within the different settings PSETs occupy.

- It would be helpful if methods instructor understood how the mediating role in stories take place and how PSETs' negotiations or actions in different settings may mediate their beliefs about writing and teaching writing.

- As PSETs narratives informed their writing instruction and pedagogy.

- PSETs' narratives displayed personal sociocultural history(ies) and experience(s) that were revisited as PSETs articulated their understandings, learning, reflections and/or face newfound knowledge.

\section{Reference}

[1] M. Beattie, "Educational leadership: Modeling, mentoring, making and re-making a learning community", European Journal of Teacher Education, 25(2-3), Taylor \& Frances, 2002, pp. 199-221.

[2] Barkhuizen, G., Benson, P., \& Chik, A. (2013). Narrative inquiry in language teaching and learning research. London: Routledge. 
[3] Ben-Peretz, M. Teacher knowledge: What is it? How do we uncover it? What are its implications for schooling? Teaching and Teacher Education, 27(1), 2011. 3-9.

[4] Bruner, J., The Culture of Education. Harvard University Press, Cambridge, MA, 1996.

[5] K. Carter, "The place of story in the study of teaching and teacher education", Educational researcher, 22-1, American Educational Research Association, 1993, pp. 518.

[6] Casey, C., Work, self, and society: After industrialism. Routledge, London, 1995.

[7] Chan, D.W.Learning to teach and teacher development: insights from the narrative therapy approach. Educational research journal. 2003.18(1):1-16

[8] Charmaz, K., Qualitative interviewing and grounded theory analysis. In Gubrium J. F. \& Holstein J. A. (Eds.). Handbook of interview research: Context and method,

SAGE Publications, Thousand Oaks, CA, 2002, pp. 675694.

[9] Charmaz, K., Grounded Theory. In J. A. Smith (Ed.) Qualitative Psychology: A Practical Guide to Research Methods, 2nd ed., SAGE Publications, Los Angeles, CA, 2008.

[10] Choi, T. H. Autobiographical reflections for teacher professional learning. Professional Development in Education, 39(5), 2013. pp. 822-840.

[11] Clandinin, D. J. and Connely, F. M. Narrative inquiry: Experience and story in qualitative research. Jossey-Bass, San Francisco, CA, 2000.

[12] Cochran-Smith, M., \& Lytle, S. L. Relationships of knowledge and practice: Teacher

learning in communities. Review of Research in Education, 24,1999. 249-305.

[13] Cole, A. L., and Knowles, J. G., Researching teaching: Exploring teacher development through reflexive inquiry. Allyn \& Bacon, Boston, MA, 2000.

[14] F. M. Connelly and D. J. Clandinin, Stories of experience and narrative inquiry. Educational researcher, 19(5), AERA, 1990, pp. 2-14

[15] M. Cortazzi, Narrative analysis. Language teaching, 27(03), SAGE Publications LTD, 1994, pp. 157-170.

[16] L. Darling-Hammond, “ Constructing 21st-century teacher education", Journal of teacher education 57(3), SAGE Publications, Thousand Oaks, CA, 2006, pp. 300314.

[17] Day, C., A passion for teaching. Routledge, London, 2004.

[18] C. Day, and R. Leitch, "Teachers' and teacher educators' lives: The role of emotion", Teaching and Teacher Education, 17(4), Elsevier Ltd., 2001, pp. 403415.

[19] Dominicé, P., Learning from Our Lives: Using Educational Biographies with Adults. Jossey Bass Publishers, San Francisco, CA, 2000.

[20] F. Elbaz, "Knowledge and discourse: The evolution of research on teacher thinking", Journal of Curriculum Studies, Taylor \& Francis, Ltd. 1990, pp. 15-42.

[21] J. Emig, Writing as a mode of learning. College Composition \& Communication (28)2, NCTE, 1977, pp.122- 127.

[22] Engström, Y., Learning by expanding: An activitytheoretical approach to developmental research, Orienta-Konsultit, Helsinki, 1987.

[23] L. Flower, and J. R. Hayes, "A cognitive process theory of writing", College composition and communication, NCTE, 1981, pp. 365-387.
[24] B. Flyvbjerg, Five Misunderstandings about CaseStudy Research. Qualitative Inquiry 12(2), 2006, pp. 219245

[25] Forde, C. Approaches to professional learning: coaching, mentoring and building collaboration. In C. Forde and J. O'Brien (Eds.), Coaching and mentoring: Developing teachers and leaders. Policy and practice in education, 29, 2011. pp. 17-31). Edinburgh: Dunedin.

[26] Frazier, E. F. (1937). Negro Harlem: An ecolocial study. American Journal of Sociology, 43, 72-88.

[27] Fulwiler, T. (1982). Writing: An act of cognition. New directions for teaching and learning (12), Wiley Periodicals Inc., 1982, pp. 15-26.

[28] Gee, J. P., "The narrativization of experience in the oral style". Journal of education, Boston University School of Education, 1985, pp. 9-35.

[29] Glaser, B. G. and Strauss, A. L. The discovery of grounded theory: strategies for qualitative research. Aldine, Chicago, 1967.

[30] Geertz, C. The interpretation of cultures: Selected essays. Vol. 5019. Basic books, 1973.

[31] Harbon, L., \& Moloney, R. (Eds.). (2013). Language teachers' narratives of practice. Cambridge: Cambridge Scholars Publishing.

[32] Golombek*, Paula R., and Karen E. Johnson. "Narrative inquiry as a mediational space: examining emotional and cognitive dissonance in second-language teachers' development." Teachers and Teaching 10, no. 3.2004: 307-327.

[33] I. Goodson, "Studying the teacher's life and work". Teaching and Teacher Education, 10(1), PergamonElsevier Science LTD, 1994, pp. 29-37.

[34] Goodson, I., and Hargreaves, A. Teachers' professional lives. Falmer Press, London, 1996.

[35] Goodson, I. and Gill, S., Narrative pedagogy: life history and learning. Peter Lang, New York, NY, 2011.

[36] Graham, R.J. Reading and writing the self: Autobiography in education and the curriculum. New York: Teachers College Press. 1991. [37] Graves, D. and Kittle, P., My quickwrites: for inside writing. Heinemann, Portsmouth, NH, 2005.

[38] P. L. Grossman, et al., Transitions into teaching: learning to teach writing in teacher education and beyond. Journal of Literacy Re-search 32, National Research Center on English Learning and Achievement, Albany, NY, 2000, pp. 631-662. ,mf

[39] P.L Grossman, and A. E. Richert, "Unacknowledged knowledge growth: A re-examination of the effects of teacher education". Teaching \& Teacher Education, 4, 1988, pp. 53-62.

[40] Hargreaves, A., \& Goodson, I. (Eds.), Teachers' professional lives. Falmer Press, London, 1996.

[41] M. R. Jalongo, "Teachers' Stories: Our Ways of Knowing”. Educational Leadership, 49(7), Asociation for Supervision and Curriculum Development, 1992.

[42] I. E. Karpiak, The Ethnographic, the Reflective, and the Uncanny Three "Tellings" of Autobiography. Journal of Transformative Education, 1(2), 2003, pp. 99-116.

[43] Kennedy, M., Form and substance in inservice teacher education. National Institute for Science Education, 1998.

[44 ] Kleinsasser, R. C. Language teachers: Research and studies in language(s) education,teaching, and learning. Teaching and Teacher Education, 29, 2013.86-96. 
[45] Kohler-Reissman, C., Narrative methods for the human sciences. John Benjamins Publishing Company, 2008.

[46] Leont'ev, A. N., Problems of the development of the mind. Progress, Moscow, 1981.

[47] Lortie, D., Schoolteacher: a sociological study. University of Chicago Press, Chicago, IL, 1975.

[48] Liu, L. B., \& Milman, N. B. Preparing teacher candidates to teach diverse student populations through reflective practice. Reflective Practice, 11, 2010. 619-630.

[49] Miller, J., Sounds of silence breaking: women, autobiography, curriculum. Peter Lang, New York, N.Y,2005.

[50] Mishler, E. G., Research interviewing: Context and narrative. Harvard University Press, Cambridge, MA,1986. [51] North, S. M., The making of knowledge in composition: Portrait of an emerging field. Upper Montclair, Boynton/Cook Publishers, NJ, 1987.

[52] J. Petraglia, "Spinning like a kite: A closer look at the pseudotransactional function of writing". JAC, 19-33, Asociation of Teachers of Advanced Composition, 1995.

[53] Poehner, M., Dynamic assessment: a Vygotskian approach to understanding and promoting L2 development. Springer Science + Business Media, Berlin, 2008.

[54] Riessman, C. K. Narrative Analysis. Qualitative Research Methods Series, vol. 30, SAGE, Newbury Park, CA, 1993.

[55] Schunk, D. Learning Theories; an educational perspective (4th Ed.). Pearson: Merill Prentice Hall, Columbus, OH, 2004.

[56] Strauss A. and Corbin J., Basics of Qualitative Research: Grounded Theory Procedures and Techniques. Sage, Newbury Park, CA, 1990.

[57] Strauss, A. and Corbin, J., Grounded Theory methodology: An overview, In Denzin, N., K. and Y.S. Lincoln, (Eds.) Handbook of Qualitative Research. SAGE Publications, London, 1994, pp. 1-18.

[58] Tomlinson, S., Multicultural education in white schools. BT Batsford Limited, London, 1990.

[59] Tsui, A. Complexities of identity formation: A narrative inquiry of an EFL teacher. Tesol Quarterly, 41,2007.657-680.

[60]Trent, J. The professional development of teacher identities in Hong Kong: Can a short-term course make a difference?. Professional development in education, 37(4), 2011, 613-632

[61] Vygotsky, L. Thought and language, (Trans.). Hanfmann, E. \& Vakar, G. The M. I. T. Press, Cambridge, MA, 1962.

[62] Vygotsky, L. S. Mind and society: The development of higher mental processes. Harvard University Press, Cambridge, MA, 1978.

[63] Wenger, E. Communities of practice: Learning, meaning, and identity, 2nd ed., Cambridge: Cambridge University Press. 2003.

[64] Witherell, C., and Noddings, N. (Eds.), Stories lives tell: Narrative and dialogue in education. Teachers College Pres., New York, NY, 1991 